No 3981

Studia nad Autorytaryzmem i Totalitaryzmem 42, nr 1

Wrocław 2020

https://doi.org/10.19195/2300-7249.42.1.6

ANDRZEJ SAKOWICZ

ORCID: 0000-0001-6599-4876

Uniwersytet w Białymstoku

sakowicz@uwb.edu.pl

\title{
Używanie symboli ideologii nazistowskiej w orzecznictwie Europejskiego Trybunału Praw Człowieka. Uwagi na podstawie spraw Nix v. Niemcy oraz Šimunić v. Chorwacja
}

\begin{abstract}
Abstrakt: Celem artykułu jest zagadnienie używania symboli ideologii nazistowskiej w orzecznictwie Europejskiego Trybunału Praw Człowieka. Współcześnie w niektórych państwach europejskich zabrania się bowiem w sferze publicznej symbolicznego posługiwania się symboliką systemów totalitarnych - czy to nazistowskiej swastyki, komunistycznego młota i sierpa, czy też jakiegokolwiek innego symbolu. Na tym tle pojawia się pytanie, jakie są granice ingerencji w wolność słowa. W sprawie Nix v. Niemcy Europejski Trybunał Praw Człowieka stwierdza, że kryminalizacja używania symboli nazistowskich ma na celu zapobieżenie odrodzeniu się nazizmu i utrzymanie pokoju politycznego. Podstawową kwestią było jednak ustalenie, czy zakaz posługiwania się symbolami ideologii nazistowskiej w przestrzeni publicznej może być uznany jako ingerencja „niezbędna w demokratycznym społeczeństwie” w wolność wyrażania opinii. ETPCz uznał, że wskazana przesłanka została zrealizowana. Czyniąc rozważania w tym zakresie, słusznie przyjął, że ,państwa, które doświadczyły okrucieństw nazizmu, mogą zostać uznane za "państwa, na których spoczywa szczególna odpowiedzialność moralna, by zdystansować się od masowych potworności popełnionych przez nazistów «". ETPCz dodał, że nie tylko propagowanie nazizmu winno być karalne, lecz także posługiwanie się symboliką nazistowską w celu przyciągnięcia uwagi czytelnika. Ma to bowiem uniemożliwić przyzwyczajenie ludzi do symboli ideologii nazistowskiej bądź dopuszczania do ich tolerowania, zwłaszcza w państwie tak historycznie doświadczonym przez nazizm jak Niemcy. Niewątpliwe sprawa Nix $v$. Niemcy ilustruje strukturalną analizę proporcjonalności w odniesieniu do wolności słowa.

W artykule poddano analizie także sprawę Šmunić v. Chorwacji, która dotyczyła piłkarza ukaranego przez władze chorwackie za to, że w trakcie meczu zwrócił się do tłumu z pozdrowieniem symbolizującym nienawiść w stosunku do ludzi różnych wyznań lub tożsamości etnicznych, co było manifestacją ideologii rasistowskiej. Wykorzystał on oficjalne powitanie organizacji Ustasza obowiązującego w czasach reżimu Niezależnego Państwa Chorwackiego. Trybunał wskazał, że skarżący użył wskazanego gestu w czasie meczu piłkarskiego wobec ogromnej widowni, na które to okrzyki widzowie odpowiedzieli, co więcej, zrobił to cztery razy. W sprawie Šimunić v. Chorwacja
\end{abstract}

Studia nad Autorytaryzmem i Totalitaryzmem 42, nr 1, 2020

(C) for this edition by CNS 
Trybunał powtórzył, że charakter i surowość nałożonej kary są czynnikami, które należy wziąć pod uwagę przy ocenie proporcjonalności ingerencji w wolność słowa.

W artykule znalazła się analiza orzecznictwa ETPCz oraz wynikające z niej wnioski.

Słowa kluczowe: symbol ideologii nazistowskiej, kryminalizacja symboliczna, prawo karne, prawa człowieka, wolność słowa.

THE USE OF SYMBOLS OF NAZI IDEOLOGY IN THE CASE-LAW

OF THE EUROPEAN COURT OF HUMAN RIGHTS: ANALYSIS BASED

ON THE CASE OF NIX V. GERMANY AND THE CASE OF ŠIMUNIĆ V. CROATIA

\section{Abstract}

The article deals with the use of symbols of Nazi ideology in the case-law of the European Court of Human Rights. At present, symbolic representations of the past order, whether the Nazi swastika, the Communist hammer and sickle or any other symbol, have been prohibited from the public sphere in some European states. Against this background, the question arises as to what are the limits to interference with the freedom of speech. In Nix v. Germany, the European Court of Human Rights notes that the criminalisation of the use of Nazi symbols is to prevent the revival of Nazism and maintain political peace. As to whether the interference was necessary, which required it to be a response to a pressing social need, the Court considered that Germany's decision to criminally sanction the use of Nazi symbols must be seen in the light of their historical role and experience with Nazism and the desire to prevent its revival. The Court added that this "gratuitous use of symbols was exactly what the provision sanctioning the use of symbols of unconstitutional organisations was intended to prevent, as it was meant to pre-empt anyone becoming used to certain symbols by banning them from all means of communication". More broadly, the case Nix v. Germany illustrates the structured proportionality analysis in relation to freedom of expression.

The article analyses also the case of Šmunić v. Croatia, which concerns a footballer who was convicted by the Croatian authorities of a minor criminal offence for addressing messages to spectators of a football match, the content of which expressed or enticed hatred on the basis of race, nationality, and faith. In fact, he used an official greeting of the Ustashe movement and totalitarian regime of the Independent State of Croatia. The Court pointed out that the applicant chanted a phrase used as a greeting by a totalitarian regime at a football match in front of a large audience to which the audience replied and that he did so four times. In the case of Šimunić v. Croatia, the Court reiterates that the nature and severity of the penalty imposed are factors to be taken into account when assessing the proportionality of the interference with the freedom of speech.

Finally, the article contains the conclusions of the analysis on case-law of the European Court of Human Rights.

Keywords: the Nazi symbol, the criminalisation of symbols, penal code, human rights, freedom of speech.

\section{Wprowadzenie}

Upływ ponad siedmiu dekad od zakończenia II wojny światowej powinien wskazywać, że społeczeństwa doświadczone zbrodniami wywodzącymi się z ideologii 
nazistowskiej ${ }^{1}$ na stałe wykluczyły jakiekolwiek przejawy jej gloryfikacji. Tymczasem w Polsce ${ }^{2}$ oraz innych państwach europejskich w dalszym ciągu zdarzają się przypadki afirmacji nazizmu oraz używanie symboli ${ }^{3}$ propagujących ideologię nazistowską, w których istotę wpisana jest nienawiść i pogarda dla ludzi innych narodowości, pochodzenia etnicznego czy wyznania. Następują one wbrew obowiązującym normom prawnym, które zakazują nie tylko publicznego propagowania faszyzmu lub innego totalitarnego ustroju państwa, lecz także kreują „,na przedpolu" tego zakazu inny zakaz, polegający na posługiwania się symboliką nazistowską lub komunistyczną ${ }^{4}$. W polskim systemie prawnym został on wyrażony w art. 256 $\S 2$ k.k. Norma określona w przepisie zakazuje produkcji, utrwalania, sprowadzania, nabywania, przechowywania, posiadania, prezentowania, przewożenia lub przesyłania druku, nagrania lub innego przedmiotu, zawierającego treści propagujące faszystowski lub inny totalitarny ustrój państwa bądź nawołującą do nienawiści na tle różnic narodowościowych, etnicznych, rasowych, wyznaniowych albo ze względu na bezwyznaniowość. Przy czym warunkiem popełnienia tego czynu zabronionego jest podejmowanie wymienionych w art. $256 \S 2$ k.k. czynności w celu rozpowszechniania ideologii ${ }^{5}$.

${ }^{1} \mathrm{Na}$ temat pojęcia nazizmu oraz ideologii nazistowskiej szerzej zob. T. Scheffler, Przestępstwo publicznego propagowania faszystowskiego lub innego totalitarnego ustroju państwa (art. 256 k.k.). Analiza doktrynologiczna wybranych wypowiedzi piśmiennictwa i judykatury. Część ogólna, „Studia nad Autorytaryzmem i Totalitaryzmem” 34, 2012, nr 3, s. 106-109; G. Steinmetz, German exceptionalism and the origins of nazism, [w:] Stalinism and Nazism: Dictatorship in Comparison, red. I. Kershaw, Cambridge 1997, s. 260-261; I. Kershaw, Hitler and the uniqueness of nazism, „Journal of Contemporary History” 39, 2004, nr 2, s. 241-246.

2 Szerzej na temat obchodów urodzin Hitlera, które zostały zorganizowane wiosną 2017 roku przez Stowarzyszenie Duma i Nowoczesność, zob. W. Kulesza, „Polskie obchody” rocznicy urodzin Hitlera w świetle prawa karnego III Rzeszy, Republiki Federalnej Niemiec i Polski, „Państwo i Prawo" 2018, nr 7, s. 7-22; P. Domagała, Jeszcze o propagowaniu faszystowskiego ustroju państwa w świetle polskiego prawa karnego (kilka uwag na marginesie artykułu prof. Witolda Kuleszy), „Państwo i Prawo” 2019, nr 5, s. 116-129.

3 Przez symbol należy rozumieć ,znak umowny, występujący zwykle w formie wizualnej, pełniący funkcję zastępczą wobec pewnego przedmiotu (pojęcia, stanu rzeczy itp.) i przywodzący ów przedmiot na myśl (budzący związane z nim reakcje)" - Stownik języka polskiego, t. 3, red. M. Szymaczak, Warszawa 1981, s. 381; zbieżnie Nowy słownik języka polskiego, red. E. Sobol, Warszawa 2003, s. 977-978.

4 Zob. A. Fijalkowski, The criminalisation of symbols of the past: Expression, law and memory, „International Journal of Law in Context” 10, 2014, nr 3, s. 295-314.

5 Por. M. Kalitowski, [w:] Kodeks karny. Komentarz, red. M. Filar, Warszawa 2010, s. 1119; M. Mozgawa, [w:] Kodeks karny. Praktyczny komentarz, red. M. Mozgawa, Warszawa 2010, s. 527; E.W. Pływaczewski, A. Sakowicz, [w:] Kodeks karny. Część szczególna. Komentarz do artykułów 222-316, t. 2, red. A. Wąsek, R. Zawłocki, Warszawa 2010, komentarz do art. 256, nb 26. Ostatnio w literaturze interesującą i pogłębioną analizę wypowiedzi doktryny i orzecznictwa na podstawie art. 256 k.k. przeprowadził T. Scheffler, Przestępstwo publicznego propagowania faszystowskiego lub innego totalitarnego ustroju państwa (art. $256 \mathrm{k.k}$.). Analiza doktrynologiczna wybranych wypowiedzi piśmiennictwa i judykatury. Część szczególna I, „Studia nad Autorytaryzmem i Totalitaryzmem" 40, 2018, nr 4, s. 145-159; idem, Przestęstwo publicznego propagowania faszystowskiego

Studia nad Autorytaryzmem i Totalitaryzmem 42, nr 1, 2020

(C) for this edition by CNS 
Podobne rozwiązania, statuujące odpowiedzialność za propagowanie ideologii nazistowskiej oraz używanie jej symboliki, znalazły się w ustawach karnych na przykład w Albanii, Niemczech, na Węgrzech i Ukrainie. W innych państwach odpowiedzialność za tego typu zachowania została umiejscowiona w ramach odpowiedzialności karnoadministracyjnej (na przykład Litwa, Chorwacja czy Rosja) ${ }^{6}$. Odmienności występują także co do motywów wprowadzenia zakazu propagowania symboli ideologii nazistowskiej bądź komunistycznej. Choć formy odpowiedzialności przybrały różną postać, powody jej wprowadzenia łączono z koniecznością poszanowania pamięci ofiar zbrodni nazistowskich, komunistycznych, która ma bezpośredni związek z ochroną: godności tych ofiar ${ }^{7}$, porządku konstytucyjnego oraz wartości demokratycznych ${ }^{8}$, zasady demokratycznego państwa prawa ${ }^{9}$, pokoju publicznego (lub politycznego) w państwie ${ }^{10}$, prawidłowego funkcjonowania państwa w sposób demokratyczny, zapewniający jego obywatelom i innym osobom zamieszkałym na jego terytorium ochronę ich prawa $^{11}$, pokoju społecznego, porządku publicznego, w tym istniejącego ładu prawnego i politycznego ${ }^{12}$, a także ,zasad demokracji, z którymi idee totalitaryzmu oraz uczucie nienawiści na tle różnic narodowościowych, etnicznych, rasowych oraz wyznaniowych są sprzeczne"13. Podkreśla się również, że zakaz publicznego używania symboli ideologii nazistowskiej ma na celu ograniczenie negatywnego wpływu tej ideologii na społeczeństwa oraz osłabienia więzi między osobami, które odwołują się do ideologii sprzecznej z ustawą zasadniczą ${ }^{14}$.

lub innego totalitarnego ustroju państwa (art. 256 k.k.). Analiza doktrynologiczna wybranych wypowiedzi piśmiennictwa i judykatury. Czesść szczególna II, „Studia nad Autorytaryzmem i Totalitaryzmem" 41, 2019, nr 1, s. 109-151.

6 I. Nuzov, Freedom of symbolic speech in the context of memory wars in Eastern Europe, „Human Rights Law Review” 19, 2019, nr 2, s. 231-253.

7 A. Fijalkowski, op. cit., s. 309-310.

8 H.U. Paeffgen, [w:] U. Kindhäuser, U. Neumann, H.U. Paeffgen, Strafgesetzbuch. Nomos Kommentar, t. 1, Baden-Baden 2005, § 86, s. 2292; K. Kühl, M. Heger, Strafgesetzbuch. Kommentar, München 2014, s. 627.

9 A. Stegbauer, The ban of right-wing extremist symbols according to section 86 a of the German Criminal Code, „German Law Journal” 8, 2007, nr 2, s. 174.

10 D. Sterberg-Liebe, [w:] Strafgesetzbuch. Kommentar, red. A. Schönke, H. Schröder, München 2010, s. 1224; K. Kühl, M. Heger, op. cit., s. 630.

11 M. Mozgawa, [w:] Kodeks karny. Praktyczny komentarz..., s. 524.

12 Por. A. Michalska-Warias, [w:] Kodeks karny. Część szczególna, t. 2, red. M. Królikowski, R. Zawłocki, Warszawa 2017, s. 330; zbieżnie Z. Ćwiąkalski, [w:] Kodeks karny. Część szczególna. Komentarz, t. 2, red. A. Zoll, Warszawa 2008, s. 1175.

13 Por. E.W. Pływaczewski, A. Sakowicz, op. cit., komentarz do art. 256, nb 2. Na temat systemów totalitarnych zob. H. Arendt, Korzenie totalitaryzmu, Warszawa 2014, passim; B. Olszewska-Dyoniziak, Antropologia totalitaryzmu europejskiego XX wieku, Wrocław 1999, s. 10 n.; R. Scruton, Źródło totalitaryzmu, [w:] Totalitaryzm a zachodnia tradycja, red. M. Kuniński, Kraków 2006, s. 57 n.; R. Legutko, Totalitaryzm i dusza ludzka, [w:] Totalitaryzm a zachodnia tradycja..., s. 46 n.

14 Zob. H.W. Laufhütte, A. Kuschel, [w:] Strafgesetzbuch. Leipziger Kommentar, t. 4, red. H.W. Laufhütte et al., Berlin 2007, § 86a, s. 103-104; w literaturze polskiej zob. W. Kulesza, Propagowanie ideologii nazistowskiej lub jej symboli w świetle niemieckiego i polskiego prawa Studia nad Autorytaryzmem i Totalitaryzmem 42, nr 1, 2020

(C) for this edition by CNS 
Nie tylko pytania o sens odpowiedzialności za propagowanie ideologii nazistowskiej oraz używanie jej symboliki nurtują prawników. Jeszcze większe kontrowersje dotyczą semantycznego ujęcia takich zakazów, które w wypadku norm prawnych statuujących odpowiedzialność karną muszą pozostawać w zgodności z konstytucyjną oraz konwencyjną zasadą nullum crimen sine lege. I nie ma przy tym znaczenia, czy będziemy mówić o kryminalizacji propagowania ideologii nazistowskiej oraz posługiwania się jej symbolami, czy o zakazie propagowania totalitarnego ustroju państwa opartego na tej doktrynie. Niezależnie od tego, jak będzie ujęty rzeczony zakaz, w każdym przypadku nastąpi — mniejsza lub większa - ingerencja w wolność wyrażania poglądów, rozumianą nie tylko jako wolność wyrażania osobistych ocen co do faktów, lecz także jako wolność prezentowania opinii, przypuszczeń, ferowania sądów w sprawach kontrowersyjnych, informowania o zjawiskach rzeczywiście występujących, ale i domniemywanych ${ }^{15}$. Współcześnie zasady demokracji i pluralizmu politycznego wymagają zapewnienia swobody wyrażania poglądów, w tym tych kontrowersyjnych i nieakceptowanych w pewnych kręgach społecznych ${ }^{16}$. Nie oznacza to jednak, że wolność wyrażania opinii jako prawo podmiotowe ma charakter nieograniczony. Potwierdzają ten fakt zarówno regulacje międzynarodowe (na przykład art. 10 ust. 2 EKPCz, art. 19 ust. 3 MPPOiP, art. 11 Karty praw podstawowych), przepisy krajowe (na przykład art. 54 ust. 2 Konstytucji RP), jak i wyroki trybunałów konstytucyjnych w Niemczech ${ }^{17}$, Polsce ${ }^{18}$ czy na Węgrzech $^{19}$. Istotną rolę w wymiarze europejskim odgrywa także orzecznictwo Europejskiego Trybunału Praw Człowieka formułowane na podstawie Konwencji o ochronie praw człowieka i podstawowych wolności.

Celem zawartych w niniejszym tekście uwag jest przedstawienie dwóch najnowszych orzeczeń ETPCz w kwestii dopuszczalności penalizacji propagowania symboli ideologii nazistowskiej. Analiza orzecznictwa strasburskiego

karnego, [w:] Zagadnienia teorii i nauczania prawa karnego. Kara łączna. Księga Jubileuszowa Profesor Marii Szewczyk, red. W. Górowski et al., Warszawa 2013, s. 210.

15 Zob. P. Sarnecki, [w:] Konstytucja Rzeczypospolitej Polskiej. Komentarz, t. 3, red. L. Garlicki, Warszawa 2003, komentarz do art. 54, s. 1-2.

16 W wyroku TK z dnia 23 marca 2006 roku, sygn. K 4/06, OTK-A 2006, nr 2, poz. 24, stwierdzono: „Swoboda wypowiedzi jest jednym z fundamentów społeczeństwa demokratycznego, warunkiem jego rozwoju i samorealizacji jednostek. Swoboda ta nie może ograniczać się do informacji i poglądów, które są odbierane przychylnie albo postrzegane jako nieszkodliwe lub obojętne".

17 Np. postanowienie BVerfG z dnia 23 maja 2006 roku, sygn. 1 BvR 204/03, Rn 13-19.

18 Wyrok TK z dnia 19 lipca 2011 roku, sygn. K 11/10, OTK-A 2011 r., nr 6, poz. 60. Trybunał Konstytucyjny stwierdził, że art. $256 \S 2$ k.k., w części obejmującej wyrazy: ,albo będące nośnikiem symboliki faszystowskiej, komunistycznej lub innej totalitarnej”, jest niezgodny z art. 42 ust. $1 \mathrm{w}$ zw. $\mathrm{z}$ art. 54 ust. 1 i art. 2 Konstytucji RP.

19 Zob. wyroki węgierskiego Trybunału Konstytucyjnego z dnia 9 maja 2000 roku, sygn. 4/2000 AB, oraz z dnia 19 lutego 2013 roku, syng. IV/2478/2012. Szerzej zob. R. Uitz, Hungarian Ban Of Totalitarian Symbols: The Constitutional Court Speaks Up Again, https://verfassungsblog.de/hungarian-ban-of-totalitarian-symbols-the-constitutional-court-speaks-up-again/ (dostęp: 10.06.2019); A. Fijalkowski, op. cit., s. 308-309.

Studia nad Autorytaryzmem i Totalitaryzmem 42, nr 1, 2020

(C) for this edition by CNS 
ma pozwolić określić granice ingerencji w wolność wypowiedzi na podstawie art. 10 EKPCz. Wytyczenie ich ma istotne znaczenie dla rozwiązań prawnych państw-stron konwencji. W tym kontekście li tylko trzeba wspomnieć, że charakter EKPCz jako umowy międzynarodowej oraz statut jej organów powoduje, iż moc wyroków ETPCz nie tylko występuje inter partes, lecz także wywiera istotny wpływ na wykładnię standardu przepisów prawa krajowego poza ramami jednostkowego rozstrzygnięcia. Skutek res interpretata wyroków ETPCz wynika zatem zarówno z wyrażonego $\mathrm{w}$ art. $1 \mathrm{EKPCz}$,obowiązku przestrzegania praw człowieka" na płaszczyźnie materialnej ${ }^{20}$, jak i z zasady subsydiarności, która nakazuje, aby w jak największym stopniu przestrzegać Konwencji na poziomie krajowym, tak aby państwo nie dawało podstaw do kierowania skarg do Trybunału, oraz z treści przepisu art. $32 \mathrm{EKPCz}$, który stanowi, że to ETPCz jest jedynym organem upoważnionym do interpretacji Konwencji i protokołów dodatkowych ${ }^{21}$. Nie można pominąć i tego, że EKPCz, tak jak każda umowa międzynarodowa ratyfikowana, ma „pierwszeństwo przed ustawą, jeżeli ustawy tej nie da się pogodzić z umową" (art. 91 ust. 2 Konstytucji RP). To pierwszeństwo uprawnia sąd do pominięcia nieuzgadnialnych z Konwencją przepisów ustawy i bezpośredniego zastosowania przez sąd krajowy normy konwencyjnej.

\section{Wolność wyrażania poglądów oraz jej ograniczenia na podstawie Europejskiej konwencji praw człowieka}

Przedstawienie problematyki zakazu propagowania symboli ideologii nazistowskiej należy rozpocząć od kilku spostrzeżeń o charakterze wstępnym na temat wolności wyrażania poglądów w świetle orzecznictwa strasburskiego. Będą one tworzyły tło rozważań nad wypowiedziami ETPCz sprawach Nix v. Niemcy oraz Šmunić v. Chorwacja w zakresie tytułowej problematyki.

Zgodnie z treścią art. 10 ust. 1 EKPCz każda osoba ma prawo do wolności wyrażania opinii. Prawo to obejmuje wolność posiadania poglądów, otrzymywania i przekazywania informacji oraz idei bez ingerencji władz publicznych i bez względu na granice państwowe. W kluczowym wyroku ETPCz Handyside v. Wielkiej Brytania, dotyczącym swobody ekspresji, stwierdzono, że stanowi ona

jeden z filarów demokratycznego społeczeństwa, [jest] podstawą jego rozwoju i warunkiem samorealizacji jednostki. [...] Nie może obejmować wyłącznie informacji i poglądów odbiera-

${ }^{20}$ L. Garlicki, [w:] Konwencja o Ochronie Praw Człowieka i Podstawowych Wolności, t. 1. Komentarz do artykułów 1-18, red. L. Garlicki, Warszawa 2010, s. 27.

21 A. Paprocka, Wplyw orzecznictwa ETPC na rozumienie konstytucyjnych praw $i$ wolności w Polsce - kilka uwag na marginesie orzecznictwa Trybunału Konstytucyjnego, [w:] XV lat obowiąywania Konstytucji z 1997 r. Księga jubileuszowa dedykowana Zdzisławowi Jaroszowi, red. M. Zubik, Warszawa 2012, s. 81; zob. interesujące uwagi A. Bodnar, Wykonywanie orzeczeń Europejskiego Trybunału Praw Człowieka w Polsce. Wymiar instytucjonalny, Warszawa 2018, s. 140 n.

Studia nad Autorytaryzmem i Totalitaryzmem 42, nr 1, 2020

(C) for this edition by CNS 
nych przychylnie albo postrzeganych jako nieszkodliwe lub obojętne, ale i takie, które obrażają, oburzają lub wprowadzają niepokój w państwie albo w jakiejś grupie społeczeństwa. Takie są wymagania pluralizmu, tolerancji i otwartości, bez których demokratyczne społeczeństwo nie istnieje $\mathrm{e}^{22}$.

Na podstawie analizy orzecznictwa organów Konwencji można stwierdzić, że ochrona wolności wyrażania opinii obejmuje wszystkie rodzaje wypowiedzi wyrażających opinie, idee albo informacje, niezależnie od ich treści oraz sposobu komunikowania się. Znajduje to potwierdzenie w wypowiedziach ETPCz oraz przedstawicieli doktryny, którzy podnoszą, że wolność wyrażania poglądów staje się najcenniejsza właśnie wtedy, kiedy prezentowane są idee, które uderzają, szokują i kwestionują ustalony porządek ${ }^{23}$. L. Garlicki stwierdza wręcz, że

nie istnieje kategoria „wypowiedzi niechronionych”, tzn. całkowicie pozostających poza ochroną art. 10 ust. 1. Ochrona ta odnosi się także do wypowiedzi rasistowskich, pornograficznych, zniesławiających i obrażających, natomiast — i taka jest funkcja art. 10 ust. 2 - władzom przysługuje możliwość poddawania ich różnego rodzaju ograniczeniom i sankcjom ${ }^{24}$.

Wolność wypowiedzi odnosi się także do swobodnego posługiwania się technicznymi środkami przekazywania wypowiedzi. Zakres przedmiotowy normy wyrażonej art. 10 EKPCz obejmuje nie tylko wypowiedzi słowne bądź pisemne,

22 Wyrok ETPCz z dnia 17 grudnia 1976 roku w sprawie Handyside v. Wielkiej Brytania, skarga nr 5493/72, A. 12, § 49; M.A. Nowicki, Komentarz do Konwencji o ochronie praw człowieka i podstawowych wolności, Warszawa 2013, s. 814. Wskazane stanowisko znalazło potwierdzenie w późniejszej linii orzeczniczej Europejskiego Trybunału Praw Człowieka; zob. np. wyrok ETPCz z dnia 8 lipca 1986 roku w sprawie Lingens v. Austria, skarga nr 8815/82, http://hudoc. echr.coe.int/eng?i=001-57523 (dostęp: 18.09.2019); wyrok ETPCz z dnia 23 kwietnia 1992 roku w sprawie Castells v. Hiszpania, skarga nr 11798/85, http://hudoc.echr.coe.int/eng?i=001-57772 (dostęp: 18.09.2019); wyrok ETPCz z dnia 1 lipca 1997 roku w sprawie Oberschlick v. Austrii, skarga nr 20834/92, http://hudoc.echr.coe.int/eng?i=001-58044 (dostęp: 18.09.2019); wyrok ETPCz z dnia 25 listopada 1999 roku w sprawie Nilsen i Johnsen v. Norwegia, skarga nr 23118/93, http:// hudoc.echr.coe.int/eng?i=001-62915 (dostęp: 18.09.2019). Zbieżne stanowisko na temat istoty wolności wyrażania poglądów (wolności słowa) wyraził Trybunał Konstytucyjny, który w wyroku z dnia 12 maja 2008 roku (sygn. SK 43/05, OTK-A 2008, nr 4, poz. 57) stwierdził, że „w funkcjonowaniu demokratycznego państwa [wolność wyrażania poglądów] przejawia się w trzech aspektach: po pierwsze: wolność słowa zapewnia obywatelom informacje niezbędne do brania udziału w społecznych debatach i w sprawowaniu demokratycznych rządów, po drugie: wolność krytyki umożliwia poddanie osób sprawujących władzę kontroli w celu wyeliminowania korupcji oraz arbitralności i po trzecie: wolność słowa sprzyja procesowi identyfikacji interesów przez obywateli oraz ich reprezentantów, a także wspieraniu kształtowania prawidłowych relacji pomiędzy rządzonymi i rządzącym”.

23 Wyrok ETPCz z dnia 3 lutego 2009 roku w sprawie Women on Waves $i$ inni v. Portugalia, skarga nr 31276/05, § 30, http://hudoc.echr.coe.int/eng?i=001-91113 (dostęp: 18.09.2019); M.A. Nowicki, Wokół Konwencji Europejskiej. Komentarz do Europejskiej Konwencji Praw Człowieka, Warszawa 2017, s. 762; zob. Ch. Grabenwarter, European Convention on Human Rights. Commentary, München-Oxford-Baden-Baden 2014, s. 254; D.J. Harris, M. O'Boyle, C. Warbrick, Law of the European Convection on Human Rights, London-Dublin-Edinburgh 1995, s. 373; W.A. Schabas, The European Convection on Human Rights, London 2015, s. 451.

24 L. Garlicki, op. cit., nb 15.

Studia nad Autorytaryzmem i Totalitaryzmem 42, nr 1, 2020

(C) for this edition by CNS 
lecz także na przykład flagę, obraz, fotografię, karykaturę czy publiczne prezentowanie symbolu związanego z politycznym ruchem lub określoną ideologią ${ }^{25}$. Obejmuje również wypowiedzi przybierające postać konkretnego zachowania ${ }^{26}$.

Swoboda wyrażania opinii nie ma charakteru nieograniczonego. Jak wynika $\mathrm{z}$ art. 10 ust. 2 EKPCz, korzystanie z wolności, o których mowa w ust. 1, może podlegać takim wymogom formalnym, ograniczeniom i sankcjom, jakie są przewidziane przez ustawę, i łączyć się z wykazaniem, czy takie ograniczenia są konieczne w społeczeństwie demokratycznym $\mathrm{z}$ uwagi na interesy bezpieczeństwa państwowego lub publicznego, ochronę porządku i zapobieganie przestępstwu, ochronę zdrowia i moralności lub ochronę praw i wolności innych osób. Państwa-strony Konwencji korzystają z pewnej autonomii przy podejmowaniu decyzji co do tego, czy ingerencja jest „konieczna w demokratycznym społeczeństwie”. Nie ma ona charakteru absolutnego i — jak trafnie wskazuje się w doktrynie korzystanie $\mathrm{z}$ niej podlega kontroli Trybunału, która będzie dokonywana przy użyciu trzech kryteriów: 1. czy istniała „nagląca konieczność społeczna” uzasadniająca ingerencję, 2 . czy „środki użyte pozostawały w proporcji do celów, które zamierzano osiągnąć” i 3. czy „powody ingerencji przedstawione przez władze państwowe były »relewantne i wystarczające«"27. Tak umotywowana „niezbędność" ingerencji, z jednej strony, stawia przed prawodawcą każdorazowo wymóg stwierdzenia rzeczywistej potrzeby dokonania w danym stanie faktycznym ingerencji w zakres prawa bądź wolności jednostki, z drugiej zaś - winna być rozumiana jako wymóg stosowania takich środków prawnych, które będą skuteczne, a więc rzeczywiście służące realizacji zamierzonych przez prawodawcę celów. Chodzi tu o środki niezbędne w tym sensie, że chronić będą określone wartości w sposób bądź w stopniu, który nie mógłby zostać osiągnięty przy zastosowaniu innych środków. Niezbędność to również skorzystanie ze środków jak najmniej uciążliwych dla podmiotów, których wolność wyrażania poglądów ulegnie ograniczeniu.

Ponadto należy dostrzec, że organy krajowe, gdy już dokonują ingerencji, muszą ją w każdym wypadku precyzyjne uzasadnić, ponieważ standard wynikający z orzecznictwa ETPCz jest rygorystycznie i jednoznacznie określony, pozostawiając krajowym instytucjom niewielki „margines swobody ocen”28. Nabiera

25 W.A. Schabas, op. cit., s. 455.

26 Wyrok ETPCz z dnia 21 października 2014 roku w sprawie Murat Vural v. Turcja, skarga nr 9540/07, § 56, http://hudoc.echr.coe.int/eng?i=001-147284 (dostęp: 18.09.2019); W.A. Schabas, op. cit., s. 455; Ch. Grabenwarter, op. cit., s. 253.

27 Na temat ograniczeń szerzej zob. L. Garlicki, op. cit., s. 599 n. oraz podane tam orzecznictwo; J. Skrzydło, Wolność stowa a wymogi bezpieczeństwa narodowego (Na tle orzecznictwa Sąu Najwyższego USA i Europejskiego Trybunału Praw Człowieka), „Państwo i Prawo” 1995, nr 9, s. 46-60; J. Kapelańska-Pręgowska, Koncepcja tzw. marginesu oceny w orzecznictwie ETPC, „Państwo i Prawo” 2007, nr 12, s. 87-99.

28 Wyrok ETPCz (Wielkiej Izby) z dnia 29 marca 2016 roku w sprawie Bédat v. Szwajcaria, skarga nr 56925/08, § 49, http://hudoc.echr.coe.int/eng?i=001-161898 (dostęp: 18.09.2019).

Studia nad Autorytaryzmem i Totalitaryzmem 42, nr 1, 2020

(C) for this edition by CNS 
to szczególnego znaczenia, kiedy ingerencja następuje w wypowiedź polityczną oraz o sprawach mających publiczne znaczenie. W takich okolicznościach ETPCz przyjmuje domniemanie, że wskazane ograniczenie wolności wypowiedzi narusza Konwencję ${ }^{29}$. Twierdzi się także, że istnienie niezbędności ingerencji w wolność wyrażania poglądów powinno zostać ustalone w odniesieniu do pojęcia „społeczeństwa demokratycznego". Konsekwencją takiej konstatacji jest to, że ocena możliwości ograniczenia wolności wypowiedzi powinna nastąpić nie tylko przy uwzględnieniu całokształtu postanowień Konwencji, lecz także wynikających z niej wartości, jak tolerancja, pluralizm i otwartość. W orzecznictwie podkreśla się również, że „niezbędność” ingerencji musi zostać wykazana „w sposób przekonywujący” oraz wynikać z „naglącej potrzeby społecznej” (pressing social need) ${ }^{30}$. Dopuszczalna ingerencja władzy publicznej w wolność wyrażania poglądów może mieć różny charakter. Mogą to być instrumenty prawa cywilnego, administracyjnego oraz karnego, przy czym te ostatnie podlegają ściślejszej kontroli ETPCz.

Kończąc ten wątek, należy podkreślić, że każdorazowe stosowanie wskazanych ograniczeń powinno następować z uwzględnieniem art. 17 EKPCz. Przepis ten

wyklucza interpretowanie swobody wypowiedzi (wyrażania opinii) jako pozwalającej komukolwiek na ,podjęcia działań lub dokonania aktu zmierzającego do zniweczenia praw i wolności wymienionych w Konwencji”. Celem tego przepisu jest wykluczenie ochronny działań, które skierowane są przeciwko wartościom leżącym u podstaw EKPCz. Wszelako nie można wykluczyć prób powoływania się na prawa zawarte w Konwencji lub w jej protokołach, aby wywieść $\mathrm{z}$ nich prawo do zachowań prowadzących do zniszczenia zapisanych w niej praw i wolności ${ }^{31}$.

29 I.C. Kamiński, Ograniczenia swobody wypowiedzi dopuszczalne w Europejskiej Konwencji Praw Człowieka. Analiza krytyczna, Warszawa 2010, s. 101.

30 W wyrokach ETPCz (Wielkiej Izby) z dnia 23 kwietnia 2015 roku w sprawie Morice v. Francja, skarga nr 29369/10, § 124, http://hudoc.echr.coe.int/eng?i=001-154264 (dostęp: 19.09.2019); z dnia 20 października 2015 roku w sprawie Pentikäinen v. Finlandia, skarga nr 11882/10, § 87, http://hudoc.echr.coe.int/eng?i=001-158279 (dostęp 19.09.2019); a ostatnio także w wyroku w sprawie Bédat v. Szwajcaria, § 48, wskazano, że ,przymiotnik »niezbędny«, w rozumieniu art. 10 ust. 2, implikuje istnienie »nagłej potrzeby społecznej«. Układającym się Państwom przysługuje pewien margines oceny, czy potrzeba taka istnieje, jednakże idzie on w parze z nadzorem na poziomie europejskim, obejmującym zarówno ustawodawstwo, jak i decyzje stosujące to ustawodawstwo, nawet te wydane przez niezawisły sąd. Trybunał jest zatem uprawniony do wydania ostatecznego orzeczenia, czy dane »ograniczenie« można pogodzić z wolnością wyrażania opinii chronioną postanowieniami art. 10 EKPCz. Zadaniem Trybunału w ramach wykonywania swojej funkcji nadzorczej nie jest zastępowanie sądów krajowych, lecz raczej weryfikacja na podstawie art. 10 decyzji wydanych przez te sądy zgodnie z ich uprawnieniami do oceny. Powyższe nie oznacza, że nadzór ten ogranicza się do upewnienia się, czy pozwane państwo wykonało swoje dyskrecjonalne uprawnienia rozsądnie, ostrożnie i w dobrej wierze; Trybunał musi spojrzeć na zaskarżoną ingerencję w świetle sprawy jako całości i rozstrzygnąć, czy była ona »proporcjonalna do realizowanego uprawnionego celu« oraz czy powody przytoczone przez władze krajowe dla jej uzasadnienia były »właściwe i wystarczające« [...]. Czyniąc tak, Trybunał musi się upewnić, że władze krajowe zastosowały standardy, które były zgodne z zasadami zawartymi w art. 10, a ponadto, że opierały się na możliwej do zaakceptowania ocenie właściwych faktów”. Szerzej zob. L. Garlicki, op. cit., nb 15.

31 M.A. Nowicki, Wokót Konwencji Europejskiej..., komentarz do art. 17.

Studia nad Autorytaryzmem i Totalitaryzmem 42, nr 1, 2020

(C) for this edition by CNS 
W konsekwencji, jeżeli wypowiedź nie odpowiada tak zwanym wartościom konwencyjnym, to należy ją traktować jako „wypowiedzą niechronioną”, wyłączoną z zakresu zastosowania art. $10 \mathrm{EKPCz}^{32}$. Z takiej możliwości ETPCz korzysta ostrożnie, w zasadzie tylko w sytuacjach „najbardziej drastycznych”33. Uznaje się bowiem, że ograniczenia zakresu swobody wypowiedzi wyrażone w art. 10 ust. 2 EKPCz stwarzają dostateczną podstawę eliminowania wypowiedzi kolidujących z aksjologicznymi fundamentami społeczeństwa demokratycznego ${ }^{34}$.

Przyglądając się praktyce orzeczniczej Trybunału, można dojść do wniosku, że tylko w wyjątkowych przypadkach, gdy nie jest możliwe połączenie wypowiedzi z proklamowanymi i gwarantowanymi wartościami wyrażonym w EKPCz, dopuszczalne staje się odwołanie do zakazu nadużywania prawa (art. $17 \mathrm{EKPCz}$ ). Dotychczas miało to miejsce w sprawach dotyczących między innymi szerzenia doktryny nazistowskiej, negowania Holocaustu i naruszania w ten sposób godności ofiar, szerzenia poglądów rasistowskich, nawoływania do dyskryminacji oraz usprawiedliwiania polityki nazistowskiej ${ }^{35}$. Nie została jednak rozciągnięta konstrukcja zakazu nadużycia prawa w kontekście propagowania symboli totalitaryzmu, w tym symboli ideologii nazistowskiej.

\section{Zakaz używania symboli ideologii nazistowskiej jako przykład uzasadnionego ograniczania wolności wyrażania poglądów}

Dotychczasowe rozważania pokazują, że wolność wyrażania poglądów, o której mowa w art. $10 \mathrm{EKPCz}$, nie ma charakteru absolutnego i może podlegać ściśle określonym ograniczeniom. Dobrze obrazuje to orzecznictwo ETPCz w kontekście propagowania symboli ideologii nazistowskiej, i tylko w zakresie tych symboli. Gdy zaś idzie o symbolikę komunistyczną, sędziowie strasburscy wyrazili odmienne stanowisko ${ }^{36}$. Nie wychodząc poza ramy niniejszego tekstu, należy wskazać, że w jednym z kluczowych orzeczeń dotyczących symboliki

32 Zob. L. Garlicki, op. cit., s. 596 oraz wskazane orzecznictwo.

33 Ibidem, nb 17.

34 Wyrok ETPCz z dnia 10 lipca 2008 roku w sprawie Soulas $i$ Others v. Francja, skarga nr 15948/03, § 48, http://hudoc.echr.coe.int/eng?i=001-87370 (dostęp: 16.09.2019); L. Garlicki, op. cit., nb 17.

35 Por. L. Garlicki, op. cit., s. 597. Na temat dwupoziomowego standardu ochrony wolności wypowiedzi, ocenianego przez pryzmat art. 10 oraz 17 EKPCz, szerzej zob. D. Keane, Attacking hate speech under article 17 of European Convention on Human Rights, „Netherlands Quarterly on Human Rights" 2007, nr 641, s. 642-678.

36 Zob. A. Sakowicz, Propagowanie symboli ideologii nazistowskiej oraz komunistycznej. (Uwagi na podstawie orzecznictwa Europejskiego Trybunału Praw Człowieka), [w:] Pro dignitate legis et maiestate iustitiae. Księga Jubileuszowa Pana Profesora Witolda Kuleszy, red. A. Liszewska, J. Kulesza, Warszawa 2020 [w druku].

Studia nad Autorytaryzmem i Totalitaryzmem 42, nr 1, 2020

(C) for this edition by CNS 
ideologii komunistycznej, w wyroku z dnia 8 lipca 2008 roku w sprawie Vajnai v. Wegrom $^{37}$, ETPCz stwierdził, że terror komunistycznych rządów jest „poważną blizną w umysłach i sercach", prezentowanie zaś symboli komunizmu może niepokoić jego ofiary i ich krewnych, którzy słusznie mogą uznać takie działanie za brak szacunku. Mimo takiego stanowiska ETPCz przyjął, że system prawny ograniczający prawa i wolności człowieka, w tym swobodę wypowiedzi, tylko po to, aby usatysfakcjonować — realne lub wyobrażone - uczucia istniejące w społeczeństwie, nie może być uznany za odpowiadający pilnej potrzebie społecznej. Za takim stanowiskiem ETPCz przemawiało także i to, że do 2008 roku, czyli do wydania wyroku, upłynęły dwie dekady od zapoczątkowania na Węgrzech demokratycznych przemian i przejścia do systemu pluralistycznego. Czas ten uczynił je państwem o ustabilizowanej demokracji (stable democracy) $)^{38}$. Nie było także przesłanek, które mogłyby sugerować istnienie rzeczywistego zagrożenia odrodzenia się dyktatury komunistycznej. Wreszcie, co może zaskakiwać, ETPCz uznał, że czerwona gwiazda jest symbolem wieloznacznym, jest też znakiem międzynarodowego ruchu robotniczego ${ }^{39}$. W konsekwencji przyjął, że symbolu czerwonej gwiazdy nie można wiązać wyłącznie z totalitarnymi rządami komunistycznymi oraz masowymi naruszeniami praw człowieka pod ich panowaniem.

Do podobnych wniosków ETPCz doszedł w sprawie Fratanoló v. Wegry ${ }^{40}$. W judykacie tym wskazał, że niezgodne $\mathrm{z}$ art. $10 \mathrm{EKPCz}$ jest tworzenie zakazów posługiwania się symboliką bez uprzedniego wykazania zagrożenia dobra prawnego. Teza ta nie powinna dziwić. Przyjęcie odmiennego zapatrywania oznaczałoby ograniczenie wykorzystywania wskazanego symbolu w kontekstach, w których ograniczenie swobody wypowiedzi nie byłoby uzasadnione. Bardziej restrykcyjne stanowisko wybrzmiało w sprawach Nix v. Niemcy oraz Šimunić v. Chorwacja, które dotyczyły użycia symboliki związanej z ideologią nazistowską. W przeciwieństwie do wyroku w sprawie Vajnai v. Wegrom w orzeczeniach związanych z symboliką nazistowską ETPCz nie miała problemów z uzasadnieniem zakazu posługiwania się symboliką ustroju totalitarnego. Podejmując próbę szerszego odniesienia się do stanowiska ETPCz, wypada rozpocząć wywód od kilku słów na temat stanów faktycznych w sprawach Nix v. Niemcy oraz Simunić v. Chorwacja.

Pierwsza ze spraw, które znalazły się w końcu przed ETPCz, dotyczyła obywatela Niemiec. Umieścił on na swoim blogu sześć wpisów. W początkowych

37 Wyrok ETPCz z dnia 8 lipca 2008 roku w sprawie Vajnai v. Wegry, skarga nr 33629/06, http://hudoc.echr.coe.int/eng?i=001-87404 (dostęp: 16.09.2019); zob. też A. Grzelak, Opinia prawna na temat zasadności dodania $w$ art. 256 Kodeksu karnego $\S 2 w$ brzmieniu uchwalonym przez Sejm 25 września 2009 r., „Zeszyty Prawnicze Biura Analiz Sejmowych” 2010, nr 1, s. 163-170.

38 Por. wyrok ETPCz z dnia 8 lipca 2008 roku w sprawie Vajnai v. Wegry, § 49.

39 W sprawie Vajnai v. Wegry wskazano wprost: „It is clear that this star also still symbolises the international workers' movement, struggling for a fairer society, as well certain lawful political parties active in different member States" - ibidem, $\S 52$.

40 Wyrok ETPCz z dnia 3 listopada 2011 roku w sprawie Fratanoló v. Węry, skarga nr 29459/10, § 25, http://hudoc.echr.coe.int/fre?i=001-107307 (dostęp: 16.09.2019).

Studia nad Autorytaryzmem i Totalitaryzmem 42, nr 1, 2020

(C) for this edition by CNS 
wpisach, w których komentował działania urzędu pracy (Bundesagentur für Arbeit) względem swojej córki, zarzucił pracownikom wskazanego urzędu skłanianie do podjęcia przez nią nisko płatnej pracy. Skarżący wskazał, że propozycja ze strony urzędu pracy miała charakter rasistowski i dyskryminacyjny, motywowany nepalskim pochodzeniem jego córki. W kolejnych wpisach podniósł, że pracownik urzędu pracy działał, opierając się na profilowaniu rasowym, ponieważ uznawał, że pochodzenie danej osoby pozostaje w związku z odniesieniem sukcesu na rynku pracy. Skarżący uznał takie zachowanie za karygodne (shameful) i nazwał urzędnika obślizgłym (slimy staff member). W jednym ze sześciu wpisów skarżący umieścił na blogu zdjęcie Heinricha Himmlera w mundurze, z widoczną swastyką na ramieniu, oraz cytat z jego wypowiedzi na temat nauczania dzieci i młodzieży w Europie Wschodniej w czasie nazistowskiej okupacji. Jak ustaliły to sądy orzekające w sprawie skarżącego, był to wpis odosobniony. Nie pozostawał w związku pozostałymi wpisami stanowiącymi krytykę działalności urzędu pracy.

Skarżący, w związku z zamieszczeniem na stronie internetowej zdjęcia H. Himmlera ze swastyką oraz zniesławieniem pracownika urzędu pracy, został skazany przez sąd rejonowy (Amtsgericht) za czyny zabronione, to jest zniesławienia urzędnika oraz wykorzystanie symbolu zakazanej organizacji i jego publiczne udostępnianie ( $\$ 86 \mathrm{a}$ ust. 1 pkt 1 oraz $\S 86$ ust. 2 niemieckiego k.k. ${ }^{41}$ ). Za oba przestępstwa została orzeczona kara łączna w wymiarze pięciu miesięcy pozbawienia wolności. Po wniesionej przez skarżącego apelacji sąd krajowy (Landgericht) nie uwzględnił środka odwoławczego w zakresie winy skarżącego, zdecydował się natomiast na redukcję orzeczonej kary łącznej. Nowa kara łączna została orzeczona w wymiarze 140 stawek dziennych grzywny przy jednoczesnej wysokości jednej stawki w wysokości 10 euro. Sąd krajowy uzasadnił swoją decyzję tym, że skarżący umieścił zdjęcie Heinricha Himmlera w mundurze, $\mathrm{z}$ widoczną swastyką, nie w celu propagowania symboli nazistowskich, lecz w celu przyciągnięcia uwagi (an eye-catching device) czytelników do jego bloga. Skarżący nie zgodził się z przyjętym rozstrzygnięciem. Wniósł skargę do ETPCz, w której zarzucił, że wyrok krajowy stanowił naruszenie jego prawa do wolności wyrażania poglądów, chronionego art. 10 EKPCz.

Europejski Trybunał Praw Człowieka nie podzielił argumentów skarżącego. Na początku swojego wywodu w sprawie Nix v. Niemcy Trybunał nie miał wątpliwości, że art. $10 \mathrm{EKPCz}$ ma zastosowanie do internetu jako środka komunikacji, publikacja zaś zdjęć w tym medium wchodzi w zakres stosowania prawa do wolności wyrażania opinii ${ }^{42}$. A priori skazanie skarżącego za umieszczenie

41 Zob. D. Sterberg-Liebe, [w:] Strafgesetzbuch. Kommentar..., red. A. Schönke, H. Schröder, s. 1224-1228; K. Kühl, M. Heger, op. cit., s. 630-633; w literaturze polskiej na temat regulacji niemieckiego kodeksu karnego zob. W. Kulesza, Propagowanie ideologii..., s. 201-216.

42 Decyzja ETPCz z dnia 13 marca 2018 roku w sprawie Nix v. Niemcy, skarga nr 35285/16, $\S$ 43, http://hudoc.echr.coe.int/eng?i=001-182241 (dostęp: 16.09.2019); na temat internetu jako środka służącego do wyrażania poglądów zob. np. wcześniejszy wyrok ETPCz z dnia 10 stycznia

Studia nad Autorytaryzmem i Totalitaryzmem 42, nr 1, 2020

(C) for this edition by CNS 
na swoim blogu internetowym zdjęcia H. Himmlera w mundurze SS, ze swastyką na ramieniu, było ingerencją $\mathrm{w}$ prawo do wolności wyrażania opinii. W celu uznania, że taka ingerencja nie narusza postanowień EKPCz, po stronie państwa jest wykazanie spełnienia przesłanek, o których mowa w art. 10 ust. 2 EKPCz. Niezbędne jest zatem ustalenie, czy ingerencja była „przewidziana przez ustawę", czy realizowała jeden lub więcej uzasadnionych prawnie celów wskazanych w art. 10 ust. 2 EKPCz, a także czy była ,niezbędna w społeczeństwie demokratycznym" do osiągnięcia tychże celów ${ }^{43}$.

Rozstrzygając sprawę Nix v. Niemcy, Trybunał wskazał, że przesłanki uzasadniające ingerencję w wolność wyrażania poglądów zostały zrealizowane. Nie było wątpliwości, że skazanie skarżącego nastąpiło na podstawie przepisów kodeksu karnego. Europejski Trybunał Praw Człowieka nie miał wątpliwości co do zasadności kryminalizacji zachowań polegających na posługiwaniu się symboliką nazistowską. Ponadto ETPCz przyjął, że celem § 86a niemieckiego k.k. jest zapobieganie odrodzeniu zakazanych organizacji lub niekonstytucyjnych idei popieranych przez te organizacje, zachowanie spokoju politycznego i zakazanie w niemieckim życiu politycznym stosowania symboli niekonstytucyjnych organizacji $^{44}$. Podstawową kwestią było jednak ustalenie, czy zakaz posługiwania się symbolami ideologii nazistowskiej w przestrzeni publicznej może być uznany za ingerencję „niezbędną w demokratycznym społeczeństwie” w wolność wyrażania opinii. Również w tej kwestii ETPCz uznał, że wskazana przesłanka została zrealizowana. Czyniąc rozważania w tym zakresie, słusznie przyjął, że „państwa, które doświadczyły okrucieństw nazizmu, mogą zostać uznane za »państwa, na których spoczywa szczególna odpowiedzialność moralna, by zdystansować się od masowych potworności popełnionych przez nazistów «"45. Sytuacja taka nie może nie wpłynąć na kształt ustawodawstwa niemieckiego w zakresie kryminalizacji posługiwania się symbolami nazistowskimi w życiu publicznym. W orzeczeniu w sprawie Nix v. Niemcy wskazano, iż na wybór ustawodawcy w zakresie kryminalizacji symboli nazistowskich oraz zakazu stosowania takich symboli

2013 roku w sprawie Ashby Donald i inni v. Francja, skarga nr 36769/08, § 34, http://hudoc.echr.coe. int/fre? $=002-7393$ (dostęp: 16.09.2020).

43 Decyzja ETPCz z dnia 13 marca 2018 roku w sprawie Nix v. Niemcy, § 43.

44 Ibidem, § 44. Z kolei F.Ch. Schroeder wskazuje, że celem penalizacji używania znaków nazistowskich jest obrona zarówno przed dążeniami narodowosocjalistycznymi, jak i przed negatywnymi wrażeniami za granicą oraz obrona szacunku dla Republiki Federalnej; zob. idem, Die Strafvorschriften der Bundesrepublik Deutschland gegen Wiedererstehung des Nationalsozialismus, [w:] Państwo prawa i prawo karne. Ksiega Jubileuszowa Profesora Andrzej Zolla, t. 2, red. P. Kardas, T. Sroka, W. Wróbel, Warszawa 2012, s. 1307; zob. też W. Kulesza, Propagowanie ideologii..., s. 210.

45 ETPCz stwierdził: „In the light of their historical role and experience, States which have experienced the Nazi horrors may be regarded as having a special moral responsibility to distance themselves from the mass atrocities perpetrated by the Nazis" - decyzja ETPCz z dnia 13 marca 2018 roku w sprawie Nix v. Niemcy, § 47.

Studia nad Autorytaryzmem i Totalitaryzmem 42, nr 1, 2020

(C) for this edition by CNS 
w życiu politycznym należy patrzeć przez pryzmat doświadczeń historycznych. Tylko bowiem w ten sposób możliwe jest utrzymanie spokoju politycznego oraz zapobieżenie odrodzeniu się nazizmu ${ }^{46}$.

Europejski Trybunał Praw Człowieka nie miał też wątpliwości, że § 86 i 86a niemieckiego k.k. są zgodne z art. 10 ust. 2 Konwencji. Uznał, że wskazane przepisy krajowe precyzyjnie określają granice zakazu posługiwania się symboliką konstytucyjnie zakazanych organizacji, a przez to pozwalają zmaterializować przesłankę niezbędności ingerencji w wolność wyrażania poglądów. W szczególności brzmienie $\S 86$ ust. 3 niemieckiego k.k. wyklucza objęcie zakazem posługiwania się symboliką nazistowską tych czynów, które służą edukacji obywatelskiej, zwalczaniu niekonstytucyjnych ruchów, promowaniu sztuki lub nauki, badaniom naukowym oraz informowaniu o bieżących i historycznych wydarzeniach lub podobnym celom. Zarówno sądy krajowe, jak i sędziowie strasburscy nie mieli wątpliwości, że przepisy karne nie znajdują zastosowania do tych zachowań, które polegają na ,jasnym i oczywistym” (obvious and clear) sprzeciwie wobec ideologii nazistowskiej wyrażonej przez określony symbol. Z uwagi na obowiązujący w niemieckim porządku prawnym zakaz używania symboli nazistowskich w niemieckim życiu politycznym ETPCz przyjął, że krytyczne wykorzystywanie przedmiotowych symboli nie wystarczy, aby doszło do wyłączenia przestępności zachowania ${ }^{47}$.

ETPCz nie miał wątpliwości, że symbol wykorzystany przez skarżącego zdjęcie Heinricha Himmlera w mundurze SS, ze swastyką na ramieniu - nie może zostać uznany za symbol o jakimkolwiek innym znaczeniu niż związanym z ideologią nazistowską. Zarówno mundur formacji SS, swastyka, jak i sama postać jednego z głównych przywódców Trzeciej Rzeszy jednoznacznie wskazują na symbolikę nazistowską. Do oceny świadomości skarżącego przy naruszeniu normy zakazującej posługiwania się symbolami nazistowskimi w niemieckim życiu politycznym nie był obojętny fakt, że sześć tygodni przed opublikowaniem przedmiotowego wpisu skarżący został skazany za zamieszczenie na blogu zdjęcia Angeli Merkel w nazistowskim mundurze i wąsikiem na wzór Adolfa Hitlera. W ocenie ETPCz okoliczność ta daje podstawę twierdzić, że skarżący miał wiedzę na temat przepisów niemieckiego kodeksu karnego w zakresie penalizacji posługiwania się symboliką nazistowską oraz praktyki sądów niemieckich w tej kwestii ${ }^{48}$.

Odrzucając skargę w sprawie Nix v. Niemcy, ETPCz dostrzegł, że skarżący nie miał zamiaru rozpowszechniania totalitarnej propagandy, podżegania do przemocy, groźby lub stosowania mowy nienawiści. Wpis skarżącego nie zawierał także żadnych odniesień bądź widocznego odesłania do wcześniejszych wpisów skarżącego, co mogłoby sugerować, że jest elementem debaty publicznej. Pomimo takiego twierdzenia ETPCz podkreślił, że skarżący wykorzystał

\footnotetext{
46 Ibidem.

47 Ibidem, $\S 48$.

48 Ibidem, $\S 13,50$.
}

Studia nad Autorytaryzmem i Totalitaryzmem 42, nr 1, 2020

(C) for this edition by CNS 
symbole nazistowskie, aby przyciągnąć uwagę czytelników do swojego bloga. Takie jednak zachowanie wpisywało się w opis czynu zabronionego w $\S 86$ i 86a niemieckiego k.k., które - jak już zostało wskazane - penalizują rozpowszechnianie symboliki organizacji nazistowskiej. Łączyło się ono z przekazaniem tej symboliki większemu kręgowi osób, który był poza kontrolą skarżącego. Wprawdzie nie było nakierowane na zmianę lub usunięcie porządku konstytucyjnego, lecz udostępnianie ich szerszej grupie osób mogło stanowić tworzenie podstaw do jego zmiany tudzież zadeklarowanie poparcia dla organizacji nazistowskiej, a tym samym celów zagrażających państwu.

Analiza wyroku w sprawie Nix v. Niemcy pozwala przyjąć, że ETPCz dopuścił możliwość pociągnięcia osób do odpowiedzialności karnej nawet w sytuacji, gdy symbole ideologii nazistowskiej są wykorzystywane krytycznie. Dopiero zachowanie, które polega na posłużeniu się symboliką nazistowską przy jednoczesnym wyrażeniu ,jasnego i oczywistego" sprzeciwu wobec tej ideologii, pozwala uznać, że nie dojdzie do realizacji odpowiedzialności karnej. W konsekwencji ETPCz nie znalazł powodów, by zanegować niemieckie rozwiązania prawne zakazujące używania symboliki nazistowskiej. Stanął na stanowisku, że nie tylko propagowanie nazizmu winno być karalne, lecz także posługiwanie się symboliką nazistowską w celu przyciągnięcia uwagi czytelnika (eye-catching device). Ma to bowiem uniemożliwić przyzwyczajenie ludzi do symboli ideologii nazistowskiej bądź dopuszczania do ich tolerowania ${ }^{49}$, zwłaszcza w państwie tak historycznie doświadczonym przez nazizm jak Niemcy.

Symbolika nazistowska stała się również przedmiotem analizy w wyroku $\breve{S}$ munić v. Chorwacja ${ }^{50}$. Stan faktyczny, jaki legł u podstaw tej sprawy, przedstawiał się w sposób następujący: skarżący został ukarany przez sąd chorwacki za to, że w trakcie meczu piłkarskiego zwrócił się do tłumu z pozdrowieniem Za dom (,Za ojczyznę”), a thum kilku tysięcy widzów odpowiedział odkrzyknął Spremni (,Gotowi”); w odpowiedzi skarżący powtórzył ten sam okrzyk trzykrotnie, thum zaś trzykrotnie mu odpowiedział. Sąd krajowy dostrzegł, że wskazany okrzyk jednoznacznie kojarzony jest $\mathrm{z}$ okresem II wojny światowej jako oficjalne pozdrowienie członków Chorwackiego Ruchu Rewolucyjnego (tak zwanych ustaszy) oraz

49 Na tak zwane tabu komunikacyjne zwrócił uwagę ETPCz w $§ 31$ decyzji z dnia 13 marca 2018 roku w sprawie Nix v. Niemcy. Zob. też postanowienie BVerfG z dnia 1 czerwca 2006 roku, sygn. 1 BvR 150/03, Rn. 18; postanowienie BVerfG z dnia 18 maja 2009 roku, sygn. 2 BvR 2202/08, Rn. 13; postanowienie BGH z dnia 1 października 2008 roku, sygn. 3 StR 164/08, NStZ 2009, s. 88-89; wyrok BGH z dnia 28 lipca 2005 roku, sygn. 3 StR 60/05, NJW 2005, s. 3223. W piśmiennictwie niemieckim wskazuje się, że celem takiego zakazu jest zatamowanie wewnętrznego oddziaływania symbolu ideologii nazistowskiej na grupę bądź umacnianie się tak samo myślących osób, które odwołują się do ideologii sprzecznej z ustawą zasadniczą; zob. H.W. Laufhütte, A. Kuschel, [w:] Strafgesetzbuch. Leipziger Kommentar..., t. 4, § 86a, s. 103-104; W. Kulesza, Propagowanie ideologii..., s. 210.

50 Decyzja ETPCz z dnia 22 stycznia 2019 roku w sprawie Šimunić v. Chorwacja, skarga nr 20373/17, http://hudoc.echr.coe.int/eng?i=001-189769 (dostęp: 19.09.2019).

Studia nad Autorytaryzmem i Totalitaryzmem 42, nr 1, 2020

(C) for this edition by CNS 
wykorzystywany w okresie istnienia Niezależnego Państwa Chorwackiego (19411945). Co więcej, pozdrowienie Za dom spremni było często umieszczane na budynkach administracji państwowej oraz umieszczane na urzędowych dokumentach Niezależnego Państwa Chorwackiego. Godzi się w tym miejscu zaznaczyć, że doktryna tego państwa była oparta na ideologii Ante Pavelicia. Wykorzystywała antyjugosławiańskie i antyserbskie uprzedzenia, odwołanie do wyższości rasowej osób o aryjsko-chorwackim pochodzeniu oraz przynależność narodu chorwackiego do świata zachodniego chrześcijaństwa przy jednoczesnej negacji prawosławia ${ }^{51}$. Nic dziwnego, że w ocenie niektórych badaczy Niezależne Państwo Chorwackie stanowiło kopię „niemieckiego wzorca narodowosocjalistycznego”, w szczególności potwierdzał to przyjęty porządek prawny, ustawy rasistowskie, istnienie represyjnego systemu kontroli policyjnej, utworzenie obozów koncentracyjnych oraz masowy terror ${ }^{52}$. Należy dodać, że idea Niezależnego Państwa Chorwackiego zakładała, iż cała struktura życia publicznego do prawidłowego funkcjonowania była ściśle zhierarchizowana, a zwieńczeniem tego systemu była osoba wodza. Centralnym ośrodkiem był Ante Pavelić, określany mianem Poglavnik, co nawiązywało do tytułu Duce Benita Mussoliniego i Führer Adolfa Hiltera. Określenie to zawsze było przedstawiane od strony pozytywnej i budowane na czterech kategoriach jako: syn narodu, bóstwo, bohater pieśni ludowych oraz żołnierz ${ }^{53}$.

Wydając wyrok wobec skarżącego, sądy krajowe nie miały wątpliwości, że ruch ustaszy wywodził się z nazizmu, w szczególności opierał się na rasizmie, a tym samym symbolizował nienawiść w stosunku do ludzi różnych wyznań lub tożsamości etnicznych i był manifestacją ideologii rasistowskiej ${ }^{54}$. Dostrzegając te okoliczności, sądy krajowe uznały skarżącego winnym wykroczenia w postaci kierowania do widzów meczu piłkarskiego wypowiedzi, których treść wyrażała nienawiść ze względu na rasę, narodowość i wyznanie oraz podżegała do takiej nienawiści ${ }^{55}$. Stanowisko to zaaprobował ETPCz, jednocześnie uznając,

51 Szerzej zob. M. Cesarz, Elementy tradycji ustaszowskiej i ich znaczenie w procesie ksztattowania się chorwackiej tożsamości narodowej po rozpadzie Socjalistycznej Federalnej Republiki Jugosławii, „Studia nad Autorytaryzmem i Totalitaryzmem” 36, 2014, nr 4, s. 69-87; idem, Doktryna rasowa Niezależnego Państwa Chorwackiego (1941-1945), „Studia nad Faszyzmem i Zbrodniami Hitlerowskimi" 32, 2010, s. 291-305; N. Bartulin, The Ideology of Nation and Race: The Creation Ustasha Regime and Its Policies toward Minorities in the Independent State of Croatia 1941-1945, Kensington 2006, s. 175-242, http://www.jasenovac-info.com/biblioteka/Bartulin2.pdf (dostęp: 10.12.2019).

52 H. Kuberski, Powstanie Niepodległego Państwa Chorwackiego (kwiecień-sierpień 1941), „Dzieje Najnowsze” 2012, nr 1, s. 78.

53 Interesującą analizę w tym zakresie prowadzi M. Czerwiński, Język propagandy $w$ Niezależnym Państwie Chorwackim. Próba charakterystyki, „Socjolingwistyka” 19, 2005, s. 66-68.

$54 \mathrm{~W} \S 44$ decyzji ETPCz z dnia 22 stycznia 2019 roku w sprawie Šimunić v. Chorwacja stwierdzono: „Ustashe movement had originated from fascism, based, inter alia, on racism, and thus symbolised hatred towards people of a different religious or ethnic identity and the manifestation of racist ideology".

55 Decyzja ETPCz z dnia 22 stycznia 2019 roku w sprawie Šimunić v. Chorwacja, § 45.

Studia nad Autorytaryzmem i Totalitaryzmem 42, nr 1, 2020

(C) for this edition by CNS 
że skazanie skarżącego nie łączyło się z naruszeniem warunków ograniczenia wolności odnośnie do wyrażenia poglądów zawartych w art. 10 ust. 2 EKPCz. Zajmując wskazane stanowisko, ETPCz zwrócił uwagę na kontekst, w jakim nastąpiło użycie oficjalnego pozdrowienia ustaszy w okresie reżimu Niezależnego Państwa Chorwackiego. Po pierwsze, stwierdził, że użycie pozdrowienia ustaszy miało miejsce w czasie meczu piłkarskiego wobec ogromnej widowni, na które to okrzyki widzowie odpowiedzieli. Po drugie, skarżący użył czterokrotnie pozdrowienia $Z a$ dom. Po trzecie, w ocenie ETPCz skarżący, będąc znanym piłkarzem i wzorem dla wielu fanów piłki nożnej, powinien mieć świadomość możliwego negatywnego wpływu prowokacyjnych okrzyków na zachowanie widzów meczu, ergo skarżący powinien był powstrzymać się od opisanego zachowania ${ }^{56}$.

Europejski Trybunał Praw Człowieka nie doszukał się w sprawie Šimunić v. Chorwacja naruszenia wymogu niezbędności ograniczenia wolności wyrażania poglądów w kontekście oceny proporcjonalności wymierzonej skarżącemu kary. W tym względzie wziął pod uwagę charakter i dolegliwość wynikającą z nałożonej kary, kontekst reakcji na konkretną wypowiedź, względy prewencyjne, w tym ewentualne zniechęcenie potencjalnych autorów przyszłych wypowiedzi. Biorąc pod uwagę te elementy, Trybunał stwierdził, iż wysokość grzywny wymierzonej skarżącemu (w wymiarze 25 tysięcy chorwackich kun, czyli około 3300 euro) nie była nieproporcjonalna do uprawnionego celu, który miał zostać zrealizowany. Konkludując swoje stanowisko w sprawie Šimunić v. Chorwacja, ETPCz wskazał, że ingerencja w wolność wyrażania poglądów została uzasadniona istotnymi i wystarczającymi powodami (relevant and sufficient reasons), a władze chorwackie, zważywszy na stosunkowo niedużą wysokość grzywny nałożonej na skarżącego oraz na kontekst wyrażenia przez skarżącego spornego okrzyku, osiągnęły sprawiedliwą równowagę między interesem skarżącego w wolności wypowiedzi poglądów z jednej strony a interesem społeczeństwa w promowaniu tolerancji i wzajemnego szacunku w czasie imprez sportowych, jak też zwalczania dyskryminacji poprzez sport z drugiej ${ }^{57}$.

\section{Uwagi końcowe}

Analiza orzecznictwa ETPCz na postawie dwóch spraw: Nix v. Niemcy oraz Šimunić v. Chorwacja skłania do kilku uwag, które nie mogą zostać wyrażone

56 Ibidem.

$57 \mathrm{~W} \S 48$ decyzji ETPCz z dnia 22 stycznia 2019 roku w sprawie Šimunić v. Chorwacja, stwierdzono: ,the disputed interference was supported by relevant and sufficient reasons and that the authorities of the respondent State, having regard to the relatively modest nature of the fine imposed on the applicant and the context in which the applicant shouted the impugned phrase, struck a fair balance between the applicant's interest in free speech, on the one hand, and the society's interests in promoting tolerance and mutual respect at sports events as well as combating discrimination through sport on the other hand, thus acting within their margin of appreciation".

Studia nad Autorytaryzmem i Totalitaryzmem 42, nr 1, 2020

(C) for this edition by $\mathrm{CNS}$ 
w sposób stanowczy. Nieliczne wypowiedzi Trybunału w przedmiocie zakazu propagowania symboli ideologii nazistowskiej powstrzymują przed jednoznacznym konkluzjami.

Mimo to, po pierwsze, należy stwierdzić, że ETPCz, oceniając regulacje krajowe, dopuszcza możliwość penalizacji publicznego propagowania ideologii nazistowskiej. Spełnienie standardu strasburskiego nie wymaga istnienia regulacji przybierających postać esencjonalistyczną, na przykład propagowania ustroju państwa opartego na ideologii nazistowskiej. Niemniej jednak, mając na względzie wagę wolności wyrażania poglądów w życiu jednostki oraz w sferze publicznej, istnienie regulacji krajowych określających czynność sprawczą przez propagowanie totalitarnego ustroju państwa (a nie określonej doktryny) należy ocenić pozytywnie. Materializuje się bowiem wyższy standard w realizacji zasady określoności, a przez to ograniczenie nie tylko pola ideologicznie nacechowanych interpretacji ${ }^{58}$, lecz także możliwości arbitralnej ingerencji w prawo jednostki określone w art. 10 ust. 1 EKPCz.

Po drugie, ETPCz uzasadniał istnienie zakazu propagowania symboli ideologii nazistowskiej potrzebą wzmocnienia ochrony porządku prawnego, spokoju politycznego oraz funkcjonowania państwa wolnego od nienawiści na tle różnic narodowościowych bądź etnicznych. Dodano także, że potrzeba wprowadzenia zakazu propagowania symboli ideologii nazistowskiej nie może się ostać bez uwzględnienia doświadczeń historycznych danego państwa.

Po trzecie, ETPCz wskazał, że warunkiem dopuszczalności ograniczeń w korzystaniu z wolności wyrażenia poglądów jest spełnienie wymogu jej „niezbędności w społeczeństwie demokratycznym”. Jak przyjmuje Trybunał, przesłanka ta każdorazowo stawia przed prawodawcą krajowym wymóg stwierdzenia rzeczywistej potrzeby dokonania $\mathrm{w}$ danym stanie faktycznym ingerencji $\mathrm{w}$ zakres prawa bądź wolności jednostki. Ponadto przesłanka ta powinna być rozumiana jako wymóg stosowania takich środków prawnych, które będą skuteczne, a więc rzeczywiście służące realizacji zamierzonych przez prawodawcę celów. Niezbędność to również skorzystanie ze środków jak najmniej uciążliwych dla podmiotów, których prawa lub wolności zostaną ograniczone. Ingerencja w sferę wolności wyrażania poglądów musi więc pozostawać w racjonalnej i odpowiedniej proporcji do celów, których ochrona uzasadnia dokonane ograniczenie w świetle

58 Trafnie wskazuje T. Scheffler, że: „Doktryna jest czymś szerszym i większym od konkretnych postulatów ustrojowych, nie jest zatem uprawomocnione redukowanie konkretnej doktryny wyłącznie do określonych rozwiązań ustrojowych" — idem, Przestępstwo publicznego propagowania faszystowskiego lub innego totalitarnego ustroju państwa (art. 256 k.k.). Analiza doktrynologiczna wybranych wypowiedzi piśmiennictwa i judykatury. Część ogólna, s. 113. W literaturze polskiej należy także zwrócić uwagę na tekst A. Romkowskiego, Artykut $256 \S 1$ kk w świetle wyrażonej w art. 42 ust. 1 Konstytucji zasady nullum crimen sine lege (certa), „Przegląd Prawno-Ekonomiczny" 2018, nr 3, s. 72-92, w którym autor zasadnie wskazuje, że ustalenie, czy zakres kryminalizacji dotyczy propagowania określonej ideologii, czy opartego na nim danego ustroju państwa, ma istotne znacznie z perspektywy konstytucyjnej zasady określoności.

Studia nad Autorytaryzmem i Totalitaryzmem 42, nr 1, 2020

(C) for this edition by CNS 
art. 10 ust. 2 EKPCz. Jednocześnie ETPCz przyjął, że art. 10 EKPCz należy interpretować z uwzględnieniem art. $17 \mathrm{EKPCz}$, tak by wykluczyć interpretowanie swobody wypowiedzi w sposób pozwalający komukolwiek na „podjęcie działań lub dokonanie aktu zmierzającego do zniweczenia praw i wolności wymienionych w Konwencji”.

Po czwarte wreszcie, z wyroku w sprawie Nix v. Niemcy bezpośrednio, a z wyroku w sprawie Šimunić v. Chorwacja pośrednio wynika, że propagowanie symboli ideologii nazistowskiej może podlegać penalizacji w świetle art. $10 \mathrm{EKPCz}$ nie tylko wówczas, gdy sprawca działa w zamiarze bezpośrednim, lecz także gdy wykorzystuje symbolikę nazistowską jedynie w celu przyciągnięcia uwagi widza lub czytelnika. Również takie działanie uznawane jest za naganne i nie zasługuje na ochronę wynikającą z $10 \mathrm{EKPCz}$.

\section{Bibliografia}

Arendt H., Korzenie totalitaryzmu, Warszawa 2014.

Bartulin N., The Ideology of Nation and Race: The Creation Ustasha Regime and Its Policies toward Minorities in the Independent State of Croatia 1941-1945, Kensington 2006, http://www.jasenovac-info.com/biblioteka/Bartulin2.pdf (dostęp: 10.12.2019).

Barosz R., Glosa do wyroku ETPC z dnia 24 czerwca 2012 r., skarga nr 40721/08, LEX 2012.

Bodnar A., Wykonywanie orzeczeń Europejskiego Trybunału Praw Człowieka w Polsce. Wymiar instytucjonalny, Warszawa 2018.

Cesarz M., Doktryna rasowa Niezależnego Państwa Chorwackiego (1941-1945), „Studia nad Faszyzmem i Zbrodniami Hitlerowskimi” 32, 2010.

Cesarz M., Elementy tradycji ustaszowskiej i ich znaczenie w procesie ksztattowania się chorwackiej tożsamości narodowej po rozpadzie Socjalistycznej Federalnej Republiki Jugosławii, „Studia nad Autorytaryzmem i Totalitaryzmem" 36, 2014, nr 4.

Czerwiński M., Język propagandy w Niezależnym Państwie Chorwackim. Próba charakterystyki, „Socjolingwistyka” 19, 2005.

Domagała P., Jeszcze o propagowaniu faszystowskiego ustroju państwa w świetle polskiego prawa karnego (kilka uwag na marginesie artykułu prof. Witolda Kuleszy), „Państwo i Prawo” 2019, nr 5.

Fijalkowski A., The criminalisation of symbols of the past: Expression, law and memory, „International Journal of Law in Context" 10, 2014, nr 3.

Grabenwarter Ch., European Convention on Human Rights. Commentary, München-Oxford- Baden-Baden-Basel 2014.

Grzelak A., Opinia prawna na temat zasadności dodania w art. 256 Kodeksu karnego § 2 w brzmieniu uchwalonym przez Sejm 25 września 2009 r., „Zeszyty Prawnicze Biura Analiz Sejmowych" 2010, nr 1 .

Harris D.J., O’Boyle M., Warbrick C., Law of the European Convection on Human Rights, London-Dublin-Edinburgh 1995.

Kamiński I.C., Ograniczenia swobody wypowiedzi dopuszczalne w Europejskiej Konwencji Praw Człowieka. Analiza krytyczna, Warszawa 2010.

Kapelańska-Pręgowska J., Koncepcja tzw. marginesu oceny w orzecznictwie ETPC, „Państwo i Prawo" 2007, nr 12. 
Keane D., Attacking hate speech under article 17 of European Convention on Human Rights, „Netherlands Quarterly on Human Rights" 2007, nr 641.

Kershaw I., Hitler and the uniqueness of nazism, „Journal of Contemporary History” 39, 2004, nr 2. Kindhäuser U., Neumann U., Paeffgen H.U., Strafgesetzbuch. Nomos Kommentar, t. 1, Baden-Baden 2005.

Kodeks karny. Część szczególna, t. 2, red. M. Królikowski, R. Zawłocki, Warszawa 2017.

Kodeks karny. Część szczególna. Komentarz, t. 2, red. A. Zoll, Warszawa 2008.

Kodeks karny. Część szczególna. Komentarz do artykułów 222-316, t. 2, red. A. Wąsek, R. Zawłocki, Warszawa 2010.

Kodeks karny. Komentarz, red. M. Filar, Warszawa 2010.

Kodeks karny. Praktyczny komentarz, red. M. Mozgawa, Warszawa 2010.

Konwencja o Ochronie Praw Człowieka i Podstawowych Wolności, t. 1. Komentarz do artykułów 1-18, red. L. Garlicki, Warszawa 2010.

Kuberski H., Powstanie Niepodległego Państwa Chorwackiego (kwiecień-sierpień 1941), „Dzieje Najnowsze" 2012, nr 1.

Kulesza W., „,Polskie obchody” rocznicy urodzin Hitlera w świetle prawa karnego III Rzeszy, Republiki Federalnej Niemiec i Polski, „Państwo i Prawo” 2018, nr 7.

Kulesza W., Propagowanie ideologii nazistowskiej lub jej symboli w świetle niemieckiego i polskiego prawa karnego, [w:] Zagadnienia teorii i nauczania prawa karnego. Kara łączna. Księga Jubileuszowa Profesor Marii Szewczyk, red. W. Górowski, P. Kardas, T. Sroka, W. Wróbel, Warszawa 2013.

Kühl K., Heger M., Strafgesetzbuch. Kommentar, München 2014.

Leanza Ch.A., The Heckler's veto case law as a resource for democratic discourse, „Hofstra Law Review" 35, 2007.

Legutko R., Totalitaryzm i dusza ludzka, [w:] Totalitaryzm a zachodnia tradycja, red. M. Kuniński, Kraków 2006.

Machaj Ł., Wypowiedzi symboliczne w orzecznictwie Sądu Najwyższego USA, Wrocław 2011.

McGaffey R., The Heckler's veto, „Marquette Law Review” 57, 1973.

Nowicki M.A., Komentarz do Konwencji o ochronie praw czlowieka i podstawowych wolności, Warszawa 2013.

Nowicki M.A., Wokót Konwencji Europejskiej. Komentarz do Europejskiej Konwencji Praw Człowieka, Warszawa 2017.

Nowy słownik języka polskiego, red. E. Sobol, Warszawa 2003.

Nuzov I., Freedom of symbolic speech in the context of memory wars in Eastern Europe, „Human Rights Law Review" 19, 2019, nr 2.

Olszewska-Dyoniziak B., Antropologia totalitaryzmu europejskiego XX wieku, Wrocław 1999.

Paprocka A., Wpływ orzecznictwa ETPC na rozumienie konstytucyjnych praw $i$ wolności w Polsce - kilka uwag na marginesie orzecznictwa Trybunału Konstytucyjnego, [w:] XV lat obowiazywania Konstytucji z 1997 r. Księga jubileuszowa dedykowana Zdzisławowi Jaroszowi, red. M. Zubik, Warszawa 2012.

Romkowski A., Artykut $256 \S 1$ kk w świetle wyrażonej w art. 42 ust. 1 Konstytucji zasady nullum crimen sine lege (certa), „Przegląd Prawno-Ekonomiczny” 2018, nr 3.

Sakowicz A., Propagowanie symboli ideologii nazistowskiej oraz komunistycznej. (Uwagi na podstawie orzecznictwa Europejskiego Trybunału Praw Człowieka), [w:] Pro dignitate legis et maiestate iustitiae. Księga Jubileuszowa Pana Profesora Witolda Kuleszy, red. A. Liszewska, J. Kulesza, Warszawa 2020 [w druku].

Schabas W.A., The European Convection on Human Rights. Commentary, London 2015.

Scheffler T., Przestepstwo publicznego propagowania faszystowskiego lub innego totalitarnego ustroju państwa (art. 256 k.k.). Analiza doktrynologiczna wybranych wypowiedzi piśmiennictwa i judykatury. Część ogólna, „Studia nad Autorytaryzmem i Totalitaryzmem” 34, 2012, nr 3.

Studia nad Autorytaryzmem i Totalitaryzmem 42, nr 1, 2020

(C) for this edition by CNS 
Scheffler T., Przestępstwo publicznego propagowania faszystowskiego lub innego totalitarnego ustroju państwa (art. 256 k.k.). Analiza doktrynologiczna wybranych wypowiedzi piśmiennictwa i judykatury. Część szczególna I, „Studia nad Autorytaryzmem i Totalitaryzmem” 40, 2018, nr 4.

Scheffler T., Przestepstwo publicznego propagowania faszystowskiego lub innego totalitarnego ustroju państwa (art. 256 k.k.). Analiza doktrynologiczna wybranych wypowiedzi piśmiennictwa i judykatury. Część szczególna II, „Studia nad Autorytaryzmem i Totalitaryzmem” 41, 2019, nr 1 .

Schroeder F.Ch., Die Strafvorschriften der Bundesrepublik Deutschland gegen Wiedererstehung des Nationalsozialismus, [w:] Państwo prawa i prawo karne. Księga Jubileuszowa Profesora Andrzej Zolla, t. 2, red. P. Kardas, T. Sroka, W. Wróbel, Warszawa 2012.

Scruton R., Źródto totalitaryzmu, [w:] Totalitaryzm a zachodnia tradycja, red. M. Kuniński, Kraków 2006.

Skrzydło J., Wolność słowa a wymogi bezpieczeństwa narodowego (Na tle orzecznictwa Sąu Najwyższego USA i Europejskiego Trybunału Praw Człowieka), „Państwo i Prawo” 1995, nr 9.

Stownik języka polskiego, t. 3, red. M. Szymaczak, Warszawa 1981.

Stegbauer S., The ban of right-wing extremist symbols according to section 86 a of the German Criminal Code, „German Law Journal” 8, 2007, nr 2.

Steinmetz G., German exceptionalism and the origins of nazism, [w:] Stalinism and Nazism: Dictatorship in Comparison, red. I. Kershaw, Cambridge 1997.

Strafgesetzbuch. Kommentar, red. A. Schönke, H. Schröder, München 2010.

Strafgesetzbuch. Leipziger Kommentar, t. 4, red. W. Laufhütte, A.H. Kuschel, W. Schmidt, G. Bauer, D. Gmel, F.Ch. Schroeder, Berlin 2007.

Uitz R., Hungarian Ban Of Totalitarian Symbols: The Constitutional Court Speaks Up Again, https://verfassungsblog.de/hungarian-ban-of-totalitarian-symbols-the-constitutional-courtspeaks-up-again/ (dostęp: 10.06.2019). 